\title{
Komunitas Digital AIMI dan Gerakan Sosial Berbasis Facebook
}

\author{
Demeiati Nur Kusumaningrum \\ Universitas Muhammadiyah Malang \\ demeiati.nk@umm.ac.id \\ Winda Hardyanti \\ Universitas Muhammadiyah Malang \\ Winda86@gmail.com \\ Hafid Adim Pradana ${ }^{1}$ \\ Universitas Muhammadiyah Malang \\ adimhafid@gmail.com
}

\begin{abstract}
This study describes the Association of Breastfeeding Mothers Indonesia (AIMI) as an NGO that has built social movements to support breast feeding and nursing mothers in Indonesia. AIMI as a socio-political actor shapes the perception and behaviour of society to ensure the maternity right that has been recognized by the World Health Organization (WHO). This research uses qualitative-descriptive method with inductive approach. The data obtained through the online media content analysis, interviews, and literature study. It concludes thatfacebook became instrument of internalization of ideas, the dissemination of ideas, and claims of truth for AIMI where: 1) Breast milk is the best food for infants, 2) nursing is a baby and mother's rights that should be supported through government policy and infrastructure, and 3) breastfeeding barriers experienced by mothers can be overcome with well established methods and knowledge. AIMI's digital community was createdinteraction in the form of presents text and images that lead to perceptions and behaviour indirectly strengthen the enactment of Government Regulation No. 33 in 2012 and 2013 Permenkes No. 15. The online publicationhas involved AIMI
\end{abstract}

1 Tim Peneliti Pusat Kajian Sosial dan Politik (PKSP), Fakultas Ilmu Sosial dan Ilmu Politik, Universitas Muhammadiyah Malang. Email: demeiati.nk@umm.ac.id 
campaigns, educational information, socialization, training and consulting through facebook or discussion service with Lactation Counselor.

Keywords:digital community, maternity, NGO, policy, social movement

\begin{abstract}
Abstrak
Penelitian ini menggambarkan Asosiasi Ibu Menyusui Indonesia (AIMI) sebagai LSM yang membangun gerakan sosial untuk mendukung pemberian ASI dan hak ibu menyusui di Indonesia.AIMI sebagai aktor sosial-politik membentuk persepsi dan perilaku masyarakat untuk menjamin hak maternitas yang telah diakui oleh Organisasi Kesahatan Dunia (WHO). Penelitian ini menggunakan metode kualitatif-deskriptif dengan pendekatan induktif. Datadiperoleh melalui analisis konten media daring, wawancara, dan studi literatur.Hasil penelitian menyimpulkan facebookmenjadiinstrumen internalisasi ide, penyebaran gagasan, dan klaim kebenaran AIMIdi mana: 1) ASI merupakan makanan terbaik bagi bayi, 2) menyusui merupakan hak bayi dan ibu yang harus didukung melalui kebijakan dan infrastruktur, dan 3) kendala menyusui dapat diatasi dengan metode yang tepat dan pengetahuan yang mapan.Komunitas digital AIMI menghadirkan interaksi dalam bentuk teks dan gambar yang mengarah pada persepsi dan perilaku yang secara tidak langsung menguatkan pemberlakuan Peraturan Pemerintah No 33 Tahun 2012 dan Permenkes No 15 Tahun 2013. AIMI melakukan publikasi daring meliputi kampanye,informasi edukatif, sosialisasi pelatihan, dan konsultasi melalui diskusi facebook atau layanan Konselor Laktasi.
\end{abstract}

Kata kunci:gerakan sosial, kebijakan, komunitas digital, LSM, maternitas

\section{Pendahuluan}

Globalisasi mengubah cara berpikir dan perilaku masyarakat menjadi lebih "moderen" yang mana dalam kenyataannya masingmasing individu mulai merayakan kebebasan berekspresi dan berinteraksi dengan "ala" dirinya sendiri. Urusan pribadi telah menjadi konsumsi publik, tak terkecuali ranah administratif sistem pemerintahan berpeluang menjadi perdebatan hangat melalui media massa serta media sosial. Sungguh, 
Indonesia pun menikmati arus informasi yang begitu cepat, deras, dan tidak terkendali tersebut. Kemajuan teknologi dan komunikasi mendorong masyarakat mereformulasi kembali makna "pranata sosial" dan merekonstruksi arti "tradisi" yang salah satu kasusnya mengerucut pada adu argumentasi di tiap-tiap generasi. Untuk itu, tulisan ini hadir sebagai dokumentasi dan pelecut ide-ide terkait gerakan sosial baru yang berbasis pada media sosial.

Tulisan ini menggambarkan peran Asosiasi Ibu Menyusui Indonesia (AIMI)dalam mengubah persepsi dan perilaku masyarakat untuk mendukung angka keberhasilan menyusui di Indonesia. AIMI $^{2}$ lahir sebagai Lembaga Swadaya Masyarakat(LSM) yang memperjuangkan hak menyusui bagi ibu dan hak mendapatkan ASI bagi bayi. AIMI berpusat di Jakarta

2 Sekretariat AIMI berkedudukan di DKI Jakarta. Saat ini AIMI memiliki cabang di 15 provinsi yakni Sumatra Utara, Bangka Belitung, Sumatra Barat, Jambi, Lampung, Kepulauan Riau, Jawa Barat, Jawa Tengah, Yogyakarta, Jawa Timur, Bali, Kalimantan Barat, Kalimantan Timur, Kalimantan Selatan, dan Sulawesi Selatan. Serta ranting di 9 kotamadya/kabupaten di luar ibu kota provinsi yakni Depok, Cirebon, Bekasi, Bogor, Solo, Purwokerto, Bantul, Malang, dan Sorowako. dan memiliki cabang di 15 provinsi di Indonesia serta kegiatan di lebih dari 10 (sepuluh) kota besar di Indonesia (AIMI 2017).

Masalah "menyusui" menjadi bahasan maternitas yang bisa ditinjau dari sisi kesehatan, sosial, dan juga politik. Menurut sudut pandang bidang kesehatan, setiap individu baik hewan dan manusia yang digolongkan sebagai "mamalia" akan melalui siklus hidup di mana "menyusui" menjadi awal dimulainya kehidupan. Ikatan Dokter Indonesia (IDAI) mengakui bahwa ASI merupakan makanan yang sempurna bagi bayi dan mendukung metabolisme tubuh agar dapat berjalan lancar dan tubuh berkembang dengan baik.Kedekatan fisik dengan Ibu selama menyusui memberikan efek kedekatan emosional yang membantu bayi membangun ketenangan batin dan rasa percaya diri (Kusumaningrum, 2016).Sehingga, periode laktasi penting bagi tumbuh kembang manusia baik secara fisik maupun psikologis yang ke depannya berpengaruh terhadap kualitas sumber daya manusia (SDM) sebagai aset pembangunan nasional.

Aktivitas "menyusui” yang berhubungan dengan peran sosial budaya seorang "Ibu" dalam 
membentuk generasipenerus, perlu dijamin secara hukum. Mengingat, perempuan menjadi pihak yangrentan mengalami diskriminasi sosial dalam upaya memenuhi hak-haknya di ruang publik (Ruslan 2010).Peraturan Pemerintah (PP) Nomor 33 tahun 2012 mengenai Pemberian ASI Eksklusifmengamanatkan pelaksanaan Inisiasi Menyusu Dini (IMD) pasca-ibu melahirkan, pengaturan promosi susu formula dan penyediaan infrastruktur dan kebijakan yang memfasilitasi ibu menyusui di ruang publik. Hal ini dikuatkan dengan Peraturan Menteri Kesehatan RI Nomor 15 Tahun 2013 tentang Tata Cara Penyediaan Fasilitas Khusus Menyusui Dan/ Atau Memerah Air Susu Ibu (PIPIMM 2011; Kemenkes RI 2013; Kemenkes RI 2014; Kusumaningrum 2016).Sebagai konsekuensi, berbagai ruang publik seperti perkantoran, tempat rekreasi, dan pusat perbelanjaan diwajibkan menyediakan sarana yang mendukung ibu menyusui seperti 'pojok laktasi' atau 'ruang ibu dan anak'. Sehingga, sesuai dengan visi-misinya AIMI menjadi aktor sosial-politik yang berperan dalam memperjuangkan keberhasilan ibu menyusui di Indonesia salah satunya dengan memanfaatkan akun facebook (Menkes RI 2013; Kusumaningrum 2016).

\section{Metode Penelitian}

AIMI Jawa Timur menjadi subjek penelitian yang merepresentasikan AIMI Indonesia.Dengan nilai PDRB dalam peringkat3 (tiga) besar di Indonesia, Jawa Timur merepresentasikan daerah industri dan pusat perdagangan yang diasumsikan menyerap banyak tenaga kerja termasuk perempuan. Dengan demikian, Jawa Timur dianggap mewakili kondisi masyarakat modern di mana perempuan bekerja memiliki tantangan-tantangan dalam memenuhi periode menyusui.

Topik ini dianalisis menggunakan metode kualitatif-deskriptif, di mana penelitian ini lebih mengutamakan makna dan proses (Bogdan \& Biklen: 1982). Peneliti ikut berpartisipasi di lapangan, mencatat secara hatihati apa yang terjadi, melakukan analisis reflektif terhadap berbagai dokumen yang ditemukan di lapangan, dan membuat laporan secara detil (Susan Stainback: 2003). Data dianalisis secara induktif untuk menggambarkan realitas yang kompleks dan memperoleh pemahaman secara mendalam terhadap fenomena yang diteliti 
(Moleong, 2007; Harrison, 2007; Sugiyono 2009; Mulyadi 2011). Peneliti mengambil data dan informasi yang dibutuhkan untuk memperkuat argumentasi dan hasil analisis yang mendukung topik kajian, membangun kesalinghubungan, dan menyusun kesimpulan berdasarkan temuan. Data dan informasi berdasarkan analisis konten media online akan diuji keabsahannya dengan teknik observasi, studi literatur, dan wawancara.

Data primerdiperoleh melalui; (1) pengamatan sebagai anggota komunitas digital AIMI Jawa Timur (participant observation) kurun waktu 2015-2017. Penelitian ini melakukan pengamatan terhadap perilaku para ibu yang memiliki bayi (0-2 tahun), bagaimana sikap, dan cara pandangnya terhadap masalah menyusui.(2) Wawancara mendalam dilakukan terhadap sesama anggota komunitas digital AIMI Jawa Timur dan beberapa responden yang mengetahui permasalahan "ibu menyusui" di Indonesia, konselor laktasi, tenaga medis (dokter anak dan bidan) dan lembaga pelayanan kesehatan, yang mengetahui tentang PP No.33 Tahun 2012 (purposive sampling), dan (3) dokumentasi konten teks dan gambar melalui publikasi daring sebagai data sekunder.

Penelitian ini mengumpulkan ide-ide dan konten informasi yang bersumber dari publikasi tulisantulisan ilmiah tentang masalah ibu dan anak, sosialisasi permasalahan menyusui di Indonesia, artikel kesehatan yang membahas mengenai kesehatan ibu dan anak, serta konten publikasi dari AIMI Indonesia, dan akun AIMI Jawa Timur, baik dalam bentuk cetak maupun daring. Penulis secara khusus menganalis isi dari penyebaran informasi dari akun facebookAIMI Jawa Timur dan interaksi dengan komunitas AIMI dalam forum-forum diskusi daring pada akun AIMI Jawa Timur.

\section{LSM Sebagai Aktor Sosial-Politik}

Rajendra Singh (2010: 3743) dalam karya terjemahannya "Gerakan Sosial Baru" mendefinisikan gerakan sosial melalui 4 (empat) karakter: 1) Universalisme, 2) Relativisme, 3) Ide, dan 4) Pembaharuan serta Aktualisasi diri. Universalisme dipahami sebagai manifestasi perjuangan yang menuntut perubahan terhadap kondisi konflik dalam masyarakat. Persepsi konflik dapat bersumber dari kepercayaan inter subjektif maupun kolektif. Hal ini menjadi implikasi dari peran ideologi, kepemimpinan, strategi, komunikasi, mobilisasi, 
dan lain-lain yang membentuk aspek-aspek kontingen dari gerakan sosial. Sementara, karakterRelativismemerujuk pada sifat dasar, pola, arah, dan fokus gerakan sosial bervariasi sesuai dengan kultur, ruang, dan waktu.

Ide gerakan sosial pada umumnya memiliki aspirasi dan rancangan masa depan yang diinginkan. Hal ini dilakukan dengan menginternalisasi normaatau nilai, mentransformasi pengetahuan atau pemahaman, atau bahkan menggabungkan cita-cita dan hasrat kolektif sebagai proyeksi masyarakat ideal. Gerakan sosial melahirkan optimisme -utopiatentang dunia "yang lebih baik". Dengan demikian, gerakan sosial senantiasa membawa semangat pembaharuan dan aktualisasi diri. Gerakan sosial mampu menggunakan dan mencerminkan metode-metode dan strategi-strategi masyarakat untuk memperbaharui diri dan meregenerasi diri melalui aksi kolektif. Gerakan sosial berfungsi sebagai proses dan media produksi dan reproduksi masyarakat yang menandai berlangsungnya kemajuan sosial dan evolusi. Hal ini dapat diamati melalui tatanan ide, sistem relasi, tujuan kolektif, struktur dan agen yang membentuk aksi tertentu (Singh, 2010:37-43). Sehingga, penelitian ini menyakini lahirnya gerakan sosial berbasis jejaring internet sebagai bagian yang tidak terpisahkan dari modernitas masyarakat.

Peneliti memahami masyarakat sebagai sebuah lembagaatau organisasi, di mana gerakan sosial merupakan salah satu hasil dari interaksi individu-individu di dalamnya sehingga membentuk pola tertentu yang keduanya tidak dapat dianalisis secara terpisah merujuk pada pemikiran Neil J. Smelser (1962).Smelser memublikasikan karyanya yang terkenal dengan "Theory of Collective Behavior" (Locher, 2002).Tindakan sosial (collective behavior) menurut Smelser dipengaruhi oleh 4 (empat) komponen aksi sosial (social action) yaitu nilai, norma, mobilisasi, dan fasilitas. Perbedaan bentuk tindakan sosial sangat berkaitan dengan masing-masing empat komponen tersebut.

Pertama, nilai memberikan legitimasi umum untuk perilaku sosial.Dalam setiap masyarakat, perilaku individu dinilai mewakili nilai-nilai sosial yang dianut masyarakat pada umumnya. Jika perilaku individu berbenturan dengan nilainilai sosial yang secara umum diterima, maka ia akan dikucilkan. Kedua, norma memberikan pedoman khusus tentang bagaimana 
nilai-nilai ini harus diaktualisasikan dalamtindakan. Norma adalah aturan formal yang bersumber dari hukum atau informal yang kita diharapkan untuk diikuti oleh individu dalam masyarakat. Ketiga, mobilisasi individu ditentukan oleh peran kolektif dan struktur sosial. Smelser mengajak pembaca untuk memahami bahwa perilaku sosial terjadi dalam konteks struktur sosial. Tentunya masyarakat menciptakan organisasi berbasis sosial tertentu untuk memenuhi peran-peran khusus. Organisasi sosial dan pengaruh struktur sosial diyakinidapat memengaruhi perilaku individu. Sehingga, tindakan seseorang dilatarbelakangi oleh peran tertentu yang diharapkan oleh struktur sosial masyarakat di mana ia berada. Keempat, fasilitas situasional oleh Smelser dipahami sebagai sarana dan kendala yang difasilitasi atau menghambat pencapaian tujuan. Ini termasuk instrumen, keahlian, dan pengetahuan.

AIMI merepresentasikan gerakan sosial baru yang memaksimalkan pembangunan opini publik melalui media massa dan media sosial untuk mensosialisasikan pentingnya ASI dan ibu menyusui sebagai bagian dari perwujudan hak maternitas yang diakui secara global oleh WHO. Keberhasilan periode menyusui dianggap tidak hanya menjadi hak pribadi ibu dan keluarga (ranah privat) tetapi juga menyangkut keberhasilan pembangunan di bidang kesehatan dan kesejahteraan masyarakat. Sehingga, perlindungan hukum pemerintah dan dukungan moral dari lingkungan masyarakat sangat dibutuhkan.

Melalui cara pandang tersebut, AIMI berupaya menciptakan tatanan masyarakat yang lebih baik (atau dianggap ideal) yang mendukung pemenuhan hak maternitas bagi ibu dan bayi di Indonesia.Adapun nilai dan norma yang ditanamkan LSM ini adalah seorang ibu wajib menyusui anaknya dalam kondisi apapun, sehingga berbagai kendala sebetulnya mampu diatasi bersama-sama. Mengingat secara institusional hak menyusui dan mendapatkan ASI mempunyai payung hukum yang jelas.

\section{Hak Maternitas Sebagai Isu Politik Internasional}

Masalah "ibu menyusui” tidak hanya berkembang sebagai kajian bidang kesehatan tetapi juga isu politik internasional. Maternitas turut menjadi fokus kerjasama pembangunan internasional yang didukung oleh Badan Perserikatan 
Bangsa-Bangsa (PBB). WHO mengkampanyekan dukungan terhadap menyusui melalui "World Breastfeeding Week (WBW)" pada setiap minggu pertama bulan Agustus (Kusumaningrum 2016).

Pemerintah Indonesia mengakui hak ibu menyusui secara spesifik berkaitan dengan masalah keberhasilan pembangunan. Angka Kematian Ibu (AKI) menjadi salah satu indikator kesejahteraan masyarakat di sebuah negara. Secara khusus, penurunan angka kematian ibu dan bayi menjadi target Millenium Development Goals (MDGs) yang harus didukung oleh seluruh elemen masyarakat. Berdasarkan penelitian medis, keberhasilan IMD sangat membantu pemulihan Ibu pasca-persalinan terutama pada risiko terjadinya pendarahan. Sehingga, dapat kita pahami bahwa semakin tinggi tingkat keberhasilan menyusui bayi (IMD), semakin rendah angka kematian ibu melahirkan di Indonesia (Sukarsih \& Susilowati 2013; Pamuji \& Kartana 2015; Kemenkes RI 2015).

Selain itu, maternitas menjadi isu politik yang berkaitan dengan standart internasional kesejahteraan pekerja -worker welfare. Kebijakan tersebut mengatur tentang hak melahirkan, hak menyusui, cuti melahirkan, cuti haid, upaya advokasi dan penyediaan fasilitas yang mendukung terpenuhinya hak maternitas bagi perempuan. Bahkan di beberapa negara maju, suami diizinkan cuti untuk membantu istri pasca-melahirkan dengan tetap menerima gaji sebagai bentuk apresiasi negara terhadap hak maternitasnya. Masyarakat internasional sepakat bahwa perempuan memiliki keistimewaan secara fitrah sebagai penerus keturunan di mana dalam dunia kerja perlu mendapat perlakuan yang berbeda (Donner 2007; O'Neill \& Johns 2009; UNICEF 2012; WHO 2012; FIGO 2012; Dahl 2013; Menkes RI 2013; Kemenkes RI 2014; Kemenkes RI 2015).

Kita dapat melihat perempuan bekerja pada intitusi perbankan, pabrik, dan sektor jasa ritail di mall atau pusat perbelanjaan yang ratarata memberikan waktu istirahat makan dan shalat selama 1 jam. Karyawan perempuan sesuai dengan kebijakan UU Ketenagakerjaan, secara umum diberikan cuti menstruasi (haid) 2 (dua) hari dan cuti persalinan selama 3 (tiga) bulan (Betts, 2014). PP No 33 tahun 2012 dan Permenkes No 15 tahun 2013 menjadi harapan baru bagi optimalisasi pemberian ASI bagi perempuan bekerja di Indonesia. 
Kebijakan ASI Eksklusif tersebut turut menguatkan perhatian instansi swasta. Sebagai contoh salah satu perusahaan multinasional PT. Betts Indonesia-Mojokerto, Jawa Timur yang telah menyediakan ruang laktasi dan memberikan larangan promosi susu formula pada 26 April tahun $2016^{3}$.

Peraturan Pemerintah No.33 Tahun 2012 dan Peraturan Menteri Kesehatan RI Nomor 15 Tahun 2013, memberi makna bahwa internalisasi nilai-nilai maternitas dikembagakan secara hukum untuk mengkonstruksi sistem masyarakat yang lebih berpihak kepada para ibu.Tentunya, pemerintah berkepentingan menjamin kualitas kesehatan generasi penerus bangsa yang juga merupakan aset pembangunan nasional. Dengan demikian, tingkat kesehatan masyarakat berbanding lurus dengan usia harapan hidup populasi yang turut menjadi indikator keberhasilan pembangunan dan tata kelola pemerintahan yang baik (good governance performance).

Hasil wawancara dengan bagian manajemen PT. Betts Indonesia. Malang, 8 September 2016.
Peran StrategisAIMI Jawa Timur: Sosialiasi, Edukasi, dan Media Konsultasi

Berdasarkan hasil analisis kegiatan observasi, wawancara, dan purposive sampling, dapat disimpulkan beberapa latar belakang masalah: 1.) Ibu memahami ASI adalah makanan terbaik bagi bayi, namun susu formula tetap dikonsumsi oleh bayi ketika bekerja karena diasuh bersama dengan pihak keluarga dan asisten. Produksi ASI tidak mencukupi. 2.) Ibu menyadari jumlah produksi ASI kurang dan tidak memiliki waktu cukup untuk menyediakan ASI. Sehingga, susu formula menjadi solusi yang dianggap aman. 3.) Ibu memiliki kemampuan untuk menyusui namun kurang percaya diri dengan berat badan anak yang dianggap tidak proporsional. Sehingga, bayi disamping diberikan ASI juga ditambah konsumsi susu formula supaya gemuk (Kusumaningrum, 2016).

Berdasarkan analisis konten diskusi akun AIMI Jawa Timur dari tahun 2016-2017, peneliti mendapatkan pemahaman tentang lemahnya dukungan dari lingkungan jika mengacu pada uraian Kementerian Kesehatan RI. Hal ini dimaknai sebagai bagaimana keluarga, tempat bekerja, dan 
masyarakat kurang mendapat edukasi serta berbedanya perspektif sosial-politik terkait pentingnya menyusui. Sehingga, ketika seorang ibu mengalami kendala teknis ketika hendak menyusui, lingkungan kurang mendukung dan fasilitas untuk menjamin aktivitas tersebut tidak tersedia.Oleh sebab itu, AIMI hadir sebagai agen pengetahuan dan fasilitator yang mendukung para ibu menyusui di Indonesia. AIMI membangun peran strategisnya untuk menciptakan rasa percaya diri bagi ibu menyusui dan menyebarluaskan pemahaman pentingnya dukungan semua pihak untuk kesuksesan ibu menyusui melalui beberapa hal berikut:

\section{Sosialisasi}

AIMI membangun aksi kolektif yang menanamkan nilai-nilai sosial melalui teks dan gambar. Adapun nilai dan norma yang ditanamkan adalah seorang ibu wajib menyusui anaknya dalam kondisi apapun, sehingga berbagai kendala sebetulnya mampu diatasi secara institusional (dilindungi) oleh hukum yaitu kebijakan PP No.33/2012 tentang Pemberian ASI Eksklusif, dan secara teknis oleh pendampingan para Konselor ASI, institusi layanan kesehatan dan para anggotanya. Demikian juga dengan dukungan komunitas AIMI secara
umum.Dukungan AIMI terhadap perempuan berkarir cukup besar. Salah satunya ditunjukkan dengan kampanye-kampanye yang meminta seluruh pemangku kebijakan untuk pro terhadap ibu menyusui. Memberikan tempat yang layak untuk menyusui atau memerah ASI, memberikan kesempatan ibu untuk memberikan ASI dan melindungi hak ibu menyusui untuk menuntaskan periode laktasi.

AIMI Jawa Timur mempunyai komunitas digital sejumlah kurang lebih 16.000 orang pada akun facebook. AIMI Jawa Timur diresmikan pada tanggal 8 Agustus 2010 dengan penyerahan SK dan penyematan pin oleh Ketua Umum AIMI, Mia Sutanto, di Cito Hall, Surabaya. Peresmian ini juga diramaikan dengan acara menyusui serentak dan seminar ASI oleh dr. Rizal Altway, SpA. Keanggotaan AIMI secara online bersifat terbatas (closed) di mana pada setiap akun facebook AIMI mempunyai "admin" yang berperan dalam merilis publikasi yang sifatnya informatif bagi komunitas. Penyebaran ide dan nilai-nilai baik berupa teks atau gambar dapat bersifat propaganda, misalnya poster bertajuk "Menyusui dan Bekerja" yang dalam bahasa daerah (Jawa Timur) - "Nyusoni karo nyambut gawe" (lihat gambar 
1.1.). Konten kampanye melalui poster media online tersebut memberikan makna bahwa AIMI Jawa Timur berpihak kepada perempuan berkarir atau bekerja di sektor mana pun yang mau berkomitmen untuk memberikan ASI kepada buah hatinya.

Gambar 1.1.Kampanye AIMI Jawa Timur
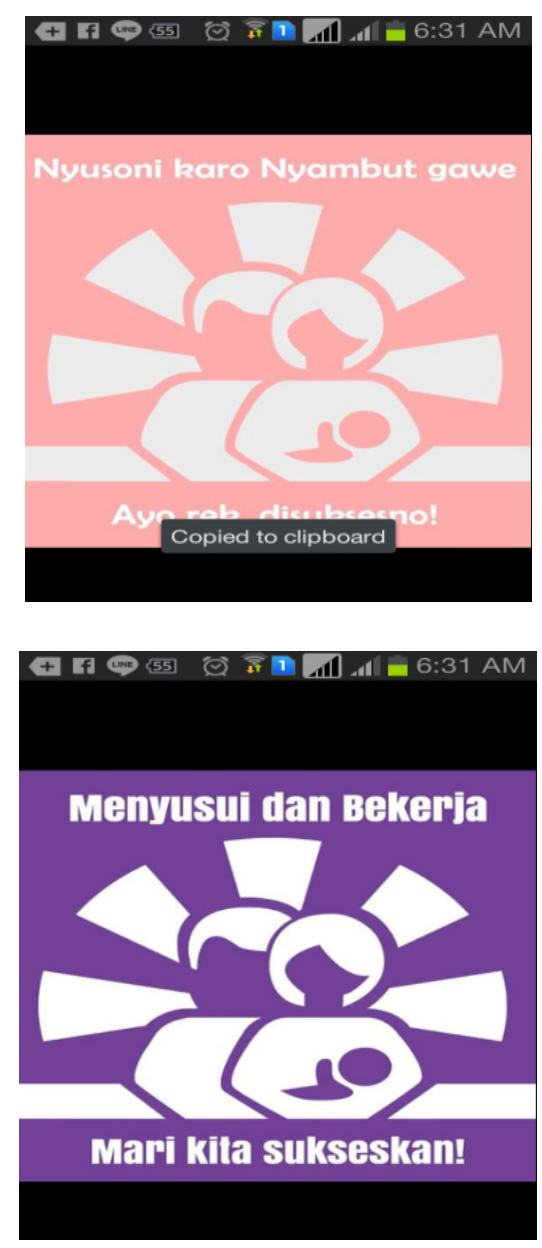

Sumber: Arsip peneliti dari Akun resmi facebook AIMI Jawa Timur
AIMI memperingati Pekan ASI Se-Dunia yang diselenggarakan pada 1-7 Agustus setiap tahunnya (Kusumaningrum 2016). Peringatan hari penting tersebut pada umumnya dijadikan head banner pada akun facebook AIMI. Lebih jauh, kepengurusan AIMI memiliki keseragaman kegiatan yang diselenggarakan di beberapa daerah yang merujuk pada misi "dukungan bagi ibu menyusui Indonesia”.Sebagai contoh, pada 24 April 2016 AIMI merayakan ulang tahun ke -9 denganmenggelar aksi di depan monumen Sura dan Baya. Melalui kegiatan 'Serentak Menyusui Laktivis Nasional SEMBILAN' AIMI di Surabaya tersebut, komunitas AIMI mengkampanyekan dukungan untuk ibu menyusui dengan serangkaian agenda lain seperti bazaar, yoga, dan konseling. Para peserta kegiatan dikenai biaya sebesar Rp 50.000,-. Para ibu menyampaikan orasinya secara terbuka menggunakan kostum hitam putih.

\section{Edukasi}

AIMI menanamkan persepsi tentangpentingnya menyusui dan ASI sebagai makanan terbaik bagi bayi melalui serangkaian kegiatan 'EdukASI' dan 'MengASIhi'. Dalam hal ini, AIMI menyebarluaskan pemahaman bahwa baik ibu yang 
bekerja full time maupun tidak, memiliki kesempatan yang sama untuk memberikan ASI Eksklusif pada bayinya. Tentunya, pasangan dan keluarga serta lingkungan terdekat harus mendukung dan memfasilitasi konsepsi tersebut. AIMI bekerjasama dengan RS Universitas Airlangga dalam menyelenggarakan kelas EdukASI pada minggu ke-empat setiap bulannya bertempat di Poli Obsgyn. Materi disampaikan oleh Ketua AIMI dr. Astri Pramarini-IBCLC tentang pengertian ASI Eksklusif, IMD (Inisiasi Menyusu Dini), manfaat ASI, kandungan ASI, cara menyusui yang benar, cara menyimpan ASI Perah, dll. (Purnamasari 2015)

Peneliti mencatat beberapa kegiatan seminar dan pelatihan yang dipublikasikan melalui akun FB AIMI Jawa Timur.Sebagai contoh, 'Kelas Edukasi MP-ASI' yang dilaksanakan pada 29 Mei 2016 di Klinik Pratama Nusa Medika Puri Mojokerto. Masing-masing peserta dikenakan biaya Rp 80.000 dengan materi 1) pentingnya pemberian MP-ASI, 2) Pedoman Umum Gizi Seimbang, 3) Makanan Batita, 4) Tantangan dalam pemberian MP-ASI, dan 5) Menu dan Resep. Selain itu, terdapat pelatihan 'Kelas Menyusui' pada 28 \& 29 Mei 2016 di RS Universitas Airlangga
Surabaya. Peserta pelatihan mendapatkan materi tentang 1) Tata laksana IMD, 2) Manfaat ASI, 3) Resiko susu formula, 4) Aturan perundang-undangan, dan 5) Tips meningkatkan produksi ASI. Pada kegiatan ini, peserta dikenakan biaya $\mathrm{Rp} 150.000$,- per orang.

Akun AIMI menjadi sumber pengetahuan bagi komunitas digitalnya, di mana terdapat publikasi informasi yang mampu menjawab kendala dan permasalahan ASI. Pengurus/admin AIMI Jawa Timur merilis artikel yang diberi judul "Manajemen ASI Perah"dan dipublikasikan pada 28 Januari 2013.Selain itu, pengelola akun $\mathrm{fb}$ AIMI Jawa Timur bernama Lianita Prawindarti mensosialisasikan beberapa materi, seperti "Media Pemberian ASIP Selain Dot dan Tips Menggunakannya" dan "ASI Lipase Tinggi” pada 23 Desember 2016.

Manfaat EdukaASI AIMI Jawa Timur telah dirasakan oleh salah satu anggota AIMI Jawa Timur yang bernama Dyah (30 tahun) responden penelitian ini, menuturkan kisahnya berjuang untuk menyusui di tengah-tengah lingkungan yang belum mendukung aktivitas ASI.Ia secara eksklusif membagikan pengalamannya melalui akun facebook pribadinya pada 20 Agustus 2016. Dyah me- 
rupakan seorang ibu pekerja. Dalam kasusnya, ia bercerita bahwa anaknya sempat menolak menyusu ibunya lantaran bingung puting. Selama ditinggal kerja 3 hari, anak Dyah terbiasa dengan dot. Dyah lalu pergi menemui Konselor Laktasi di Mojokerto dan belajar memberi ASIP melalui media botol sendok.Pada akhirnya anaknya kembali mau menyusu dengan ASI eksklusif dan secara bertahap ia sukses memenuhi periode laktasi selama 2 tahun. Dyah memberikan dukungan kepada teman-temannya sesama ibu bekerja dan para ibu berada di lingkungan yang belum memahami pentingnya ASI untuk terus berjuang dan mengedukasi sesamanya.

Begitu juga responden kami yang bernama Tia (32 tahun) merasa bangga menjadi 'Mama Perah'sebutan unik untuk seorang ibu pekerja yang masih berkomitmen memberikan ASI-. Ditengah kesibukannya bekerja di luar kota, ia bersemangat memberikan ASI eksklusif untuk anak keduanya yang masih berusia di bawah 1 tahun. Ia membagikan pengalamannya melalui akun Instagram pada 21 Februari 2016. Tiabekerja di instansi pemerintahan di Sidoarjo-Jawa Timur dengan waktu tempuh 3 jam pulang-pergi (PP) setiap harinya. Ia telah menjadi anggota komunitas AIMI lebih dari 5 tahun. Sebagai ibu perah, ia mendukung pemberian ASI Eksklusif untuk anak lakilakinya. Memerah ASI diupayakan oleh Tia selama perjalanan berangkat dan pulang kerja di dalam bis dan ketika waktu istirahat siang di musholla kantor. Tia telah menjadi anggota komunitas digital AIMI Jawa Timur sejak sebelum menikah, melalui rekomendasi oleh salah satu anggota komunitas yang kebetulan merupakan temannya.

Menurut Tia, ia rajin memantau perkembangan diskusi pada akun AIMI dan publikasi yang direkomendasikan oleh admin pada forum facebook. Sebagai contoh, Tia sangat berkomitmen terhadap asupan gizi dirinya sebagai ibu perah dan menyajikan MP-ASI anaknya hasil buatan sendiri. Menurut hasil wawancara, Tia makan 5 kali sehari. Ia mempunyai perlengkapan laktasi seperti breastpump, cooler bag, botol ASI perah, dan berbagai alat penunjang lain yang telah disarankan dalam diskusi AIMI Jawa Timur. Informasi edukatif mengenai MP-ASI pun ia dapatkan dari postingan di akun AIMI, seperti pilihan menu dan takaran kalori bagi bayi. Selain itu, Tia rajin berkonsultasi kepada konselor laktasi di RS Hermina Tangkuban 
Perahu Malang dan mengikuti perkembangan informasi terbaru melalui akun AIMI Jawa Timur. ${ }^{4}$

\section{Forum Konsultasi}

Akun FacebookAIMI Jawa Timur menjadi forum konsultasi antara sesama komunitas AIMI dan menjadi sebuah wadah bertemunya komunitas ibu menyusui dengan para konselor laktasi. Dalam akun FB AIMI sesama anggota bebas mengemukakan pendapat, keluh kesah, dan saling berbagi tips serta solusi untuk mengatasi kendalakendala menyusui tanpa menyebut merk produk tertentu dan dengan sengaja bermaksud melakukan promosi/ jual-beli.

Berdasarkan dokumentasi percakapan dalam forum AIMI, beberapa pertanyaan yang sering dikonsultasikan antara lain: 1) Sedikitnya produksi ASI dan metode meningkatkan kuantitasnya, 2) Keberadaan Konselor Laktasi di daerah masing-masing, 3) Upaya meyakinkan pihak keluarga tentang komitmen ASI Eksklusif, 4) Bentuk penampilan fisik dari ASIP yang berbeda-beda, dan 5) Lokasi rumah sakit atau lembaga layanan persalinan yang pro ASI/ IMD.Saran

4 Wawancara pada anggota komunitas AIMI di Perumahan Blimbing. Jalan Ikan Paus, Malang. 11 Januari 2016 dari para admin, konselor atau komunitas AIMI dapat mengarah pada solusi teknis. Misalnya rekomendasi jenis 'breastpump', obat untuk melancarkan ASI, dan tagging konselor laktasi yang dapat ditemui di lokasi terdekat.

Secara khusus peneliti mengamati bagaimana forum komunitas AIMI menggambarkan percakapan yang akrab meskipun satu dan lain pihak mungkin belum pernah bertemu sebelumnya. Bahkan beberapa interaksi percakapan, satu dengan yang lain saling mendukung dan memotivasi berdasarkan dari pengalaman yang sama. Interaksi komunitas digital AIMI pada akun facebook mampu menjelaskan fenomena 'global village' di mana terjadi penyeragaman pengetahuan, sikap, dan perilaku yang diakibatkan oleh perantaraan teknologi komunikasi (Nurudin, 2017:117).Akun facebook merupakan instrumen yang efektif dalam membentuk pola pikir dan keyakinan anggota komunitas AIMI, di mana semua mengetahui bahwafacebookmenjadi media sosial yang paling diminati di Indonesia (Nurudin, 2012: 179).

\section{Penutup}

AIMI hadir sebagai bentuk aksi kolektif dari persepsi 
konfik intersubjektif maupun pengaruh opini pubik dalam merespons kendala menyusui dan mengemukanya konsumsi susu formula di Indonesia sebagai pilihan para ibu. Dalam memahami menyusui sebagai isu sosial-politik, AIMI merupakan agen/ aktor yang berupaya membentuk struktur ide dan menginternalisasi pemahaman bahwa ASI merupakan makanan terbaik bagi bayi.AIMI berjuang untuk membangun sistem masyarakat yang peduli terhadap hak ibu menyusui dan hak anak mendapatkan ASI, baik berupa dukungan teknis melalui kegiatan komunitas, dan kampanye yang bertujuan mempengaruhi kebijakan sesuai dengan internasionalisasi wacara HAM oleh PBB khususnya WHO.Tulisan ini menggambarkan strategi AIMI untuk mengubah persepsi dan perilaku para Ibu dan semua pihak untuk mendukung kesuksesan periode laktasi di Indonesia.

Peran strategis AIMIdicapai dengan memanfaatkan akun facebook sebagai instrumen pelembagaan ide-ide, norma, gagasan, dan perspektif yang pro terhadap pemberian ASI dan menciptakan empati terhadap ibu menyusui. Komunitas digital AIMI Jawa Timur tidak hanya menghadirkan interaksi dalam bentuk teks dan gambar tetapi juga perubahan perilaku yang secara tidak langsung menggambarkan komitmen terhadap pemberlakuan PP No 33 Tahun 2012 dan Permenkes No 15 Tahun 2013. AIMI telah membangun langkahlangkah kongkrit melalui agenda: 1) Transfer Informasi, melalui diskusi, publikasi, komunikasi, dan testimoni pada akun FB; 2) Internalisasi ide, melalui berbagai kegiatan seminar/ workshop, sosialisasi/ kampanye, penyuluhan, dan interaksi komunitas AIMI, dan 3) Konsultasi, diskusi tanya jawab pada akun FB AIMI yang diasuh oleh para admin dan konselor laktasi.

Dari fenomena ini penulis meyakini, bahwa AIMI Jawa Timur telah berhasil membangun kepercayaan diri anggota-anggota komunitas digitalnya dengan memberikan dampak positif di mana anggota yang mengalami kendala sebagai ibu menyusui mampu mengatasi masalahnya. Persepsi ASI sebagai makanan terbaik bayi turut disebarkan melalui akun pribadi anggota AIMI yang diyakini mampu memberikan motivasi yang sama bagi para perempuan yang tengah menghadapi permasalahan periode laktasi. Hal ini merupakan dampak dari edukasi AIMI yang dibangun 
melalui kinerja cabang-cabang kepengurusan berbagai daerah khususnya di Jawa Timur melalui serangkaian seminar, pelatihan dan diskusi interaktif berkaitan dengan metode menyusui yang benar, manfaat ASI dan makanan pendamping ASI yang diagendakan secara rutin.

\section{DAFTAR PUSTAKA}

\section{Buku}

Betts Indonesia. (2014). Perjanjian Kerja Bersama 2014-2016. Mojokerto: PT. Betts Indonesia Locher, David A. (2002). Collective Behavior. New Jersey: Pearson Education. (http://www2.uvawise. edu/pww8y/Supplement/ S M S u p / C o l B e h \% 20 Lochner/01LocIntroColBeh. pdf, diakses pada 7 Juni 2017)

Moleong, Lexy J. (2007).Metode Penelitian Kualitatif.Bandung: PT Remaja Rosdakarya

Nurudin. (2012). Tuhan Baru Masyarakat Cyber di Era Digital. Yogyakarta: Aditya Media Publishing. ISBN: 978602-9461-40-4

Nurudin. (2017). Perkembangan Teknologi Komunikasi. Jakarta: Rajawali Pers. ISBN: 978-602425-115-4
Singh, Rajendra. (2010). "Gerakan Sosial sebagai Perspektif Genetik" dalam Gerakan Sosial Baru. Komisi HAM LPPM Universitas Airlangga. Yogyakarta: Resist Book. ISBN: 978-979-1097-75-8

Sugiyono. (2009). Metode Penelitian Kuantitatif Kualitatif dan R\&D. Bandung: Alfabeta. ISBN: 9798433-64-0

\section{Artikel dalam Jurnal}

Dahl, Gordon B. Dahl \& Katrine V. Løken \& Magne Mogstad \& Kari Vea Salvanes, 2016. "What Is the Case for Paid Maternity Leave?" Review of Economics and Statistics, vol 98(4), pp.655670. (http://www.nber.org/ papers/w19595, diakses 7 Juni 2017)

Kusumaningrum, Demeiati Nur. (2016). "Rasionalitas Kebijakan Pro Laktasi Indonesia," Jurnal Sospol Vol 2 No 1 (Juli-Desember 2016). (http://ejournal.umm.ac.id/ index.php/sospol/article/ viewFile/3625/4123, diakses 26 Februari 2017)

Mulyadi, Mohammad. (2011). "Penelitian Kuantitatif dan Kualitatif Serta Pemikiran Dasar Menggabungkannya", Jurnal Studi Komunikasi dan Media. 
Vol 15 No 1 (2011) pp.127138. (http://www2.uvawise. edu/pww8y/Supplement/ S M S u p / C ol B e h \% 20 Lochner/01LocIntroColBeh. pdf, diakses 7 Juni 2017)

Pamuji, Siti Erniyati Berkah \& Kartana, Tri Jaka. (2015). "Hubungan Antara Usia Ibu Dengan Involusi Uteri Pada Ibu Postpartum", Jurnal Ilmu Teknologi dan Kesehatan. Vol 3 No 2 (2015). (http:// ojs.stikesbhamada.ac.id/ojs/ index.php/jitk/article/view/87, diakses 7 Juni 2017)

Ruslan, Murniati. (2010). "Pemberdayaan Perempuan Dalam Dimensi Pembangunan Berbasis Gender". Jurnal Musawa, Vol. 2, No. 1, Juni 2010.pp.79-96. (http:// download.portalgaruda.org/ article.php? article $=185721 \& \mathrm{v}$ al $=6439 \&$ title $=$ PEMBERDAY AAN\%20PEREMPUAN\%20 DALAM\%20DIMENSI\%20 P E M B A N G U N A N \% 20 BERBASIS\%20GENDER, diakses 7 Juni 2017)

Sukarsih, Sri \& Susilowati, Endang. (2013). "Pengaruh Inisiasi Menyusu Dini Pada Kontraksi Uterus Ibu Bersalin di BPS Kecamatan Bluto", Jurnal Wiraraja Medika. Vol 3 No
1 (2013). (http://ejournal. wiraraja.ac.id/index.php/FIK/ article/view/41, diakses 7 Juni 2017)

\section{Dokumen resmi:}

Donner, Lissa. (2007). "Maternity Matters". Publikasi Women and Health Care Reform. Kanada: Canadian Women's Health Network.ISBN 9780-9783104-1-7. (http://www. womenandhealthcarereform. $\mathrm{ca} /$ publications/maternity_ en.pdf, diakses 7 Juni 2017)

FIGO. (2012). "Ethical Issues in Obstetrics and Gynelogy". Publikasi Oktober 2012. The FIGO Committee for the Study of Ethical Aspects of Human Reproduction and Women's Health. London: FIGO House. (http://www.figo.org/sites/ default/files/uploads/wgpublications/ethics/English\%20 Ethical\%20Issues\%20in\%20 Obstetrics \% 20 a n d \% 20 Gynecology.pdf, diakses 7 Juni 2017)

Kemenkes RI. (2014). “Mother's Day: Situasi Kesehatan Ibu". Publikasi Pusat Data dan Informasi. Kementerian Kesehatan RI: Jakarta. (http:// www.depkes.go.id/resources/ download/pusdatin/infodatin/ 
infodatin-ibu.pdf, diakses 7 Juni 2017)

Kemenkes RI. (2015). "Mari Dukung Menyusui dan Bekerja”. Publikasi Pusat Data dan Informasi dalam Rangka Pekan ASI Sedunia. Kementerian Kesehatan RI: Jakarta. ISSN 2442-7659. (http://www.depkes.go.id/ resources/download/pusdatin/ infodatin/infodatin-ASI.pdf, diakses 7 Juni 2017)

Menkes RI. (2013). Peraturan Menteri Kesehatan RI Nomor 15 Tahun 2013 Tentang Tata Cara Penyediaan Fasilitas Khusus Menyusui Dan/ Atau Memerah Air Susu Ibu. Kementerian Kesehatan Republik Indonesia. (http:// www.kesjaor.kemkes.go.id/ documents/01_Permenkes\%20 No.15\%20th n \%202013\%20 ttg\%20Fasilitas\%20Khusus\%20 Menyusui $\% 20$ d a n $\% 20$ Memerah\%20ASI.pdf, diakses 7 Juni 2017)

O’Neill, Marjorie \& Robyn, Johns (2009). "The History of Welfare and Paid Maternity Leave in Australia”. Julia Connell, Denise Jepsen, Robyn Johns and Keri Spooner (eds.). Theme: Advancing the Quality of HRM \& HRD in the Global
Economy.17th International Employment Relations Association (IERA) Conference. Bangkok, July 9, 2009 - Book of Proceedings. pp.172-196. ISBN 978-0-9750131-9-9. (https:// opus.lib.uts.edu.au/bitstream/1 0453/11435/1/2009001270OK. pdf, diakses 7 Juni 2017)

PIPIM (2011)."Peraturan". Rilis Pusat Informasi Produk Industri dan Makanan. Copyright 2011. (http://www.pipimm.or.id/ admin/file/peraturan/PP\%20 ASI.pdf, diakses 26 Februari 2017)

UNICEF. (2012). "Kesehatan Ibu \& Anak". Publikasi Ringkasan Kajian UNICEF di Indonesia pada Oktober 2012. (https:// www.unicef.org/indonesia/id/ A5_-_B_Ringkasan_Kajian_ Kesehatan_REV.pdf, diakses 7 Juni 2017)

WHO (2012). "Respectful Maternity Care: The Universal Rights of Childbearing Women". Publikasi World Health Organization (WHO) United Nations (UN). (http:// w w w. who.in t/ wo m a n child_accountability/ierg/ reports/2012_01S_Respectful_ Maternity_Care_Charter_ The_Universal_Rights_of_ 
Childbearing_Women.pdf, diakses 7 Juni 2017)

\section{Website Resmi}

AIMI (2017). "Organisasi”. Asosiasi Ibu Menyusui Indonesia (AIMI). (https://aimi-asi.org/organisasi, diakses 6 Juni 2017)

Purnamasari, Kartika Dewi (2015).

"Kelas EdukASI Universitas Airlangga Bersama AIMI Jatim (Asosiasi Ibu Menyusui Indonesia)". Rilis berita 2 Agustus 2015 oleh Rumah Sakit Universitas Airlangga. (http://rumahsakit.unair.ac.id/ website/kelas-edukasi-rumahsakit-universitas-airlanggabersama-aimi-jatim-asosiasiibu-menyusui-indonesia-jawatimur/, diakses 19 Juni 2017) 